Елена Л. Березович

UDK 81'373.21(470-17)

Уральский федеральный

университет ${ }^{*}$

Анна А. Макарова

Уральский федеральный университет*

Ирма И. Муллонен

Институт языка, литературы и истории

Карельского научного центра РАН**

\title{
«ДЕМОНОЛОГИЧЕСКИЕ» НАЗВАНИЯ В РУССКОЙ И СУБСТРАТНОЙ ТОПОНИМИИ РУССКОГО СЕВЕРА И КАРЕЛИИ (НА МАТЕРИАЛЕ ОСНОВ ЧЕРТ- И HIISI-) ${ }^{* * *}$
}

Статья посвящена контрастивному изучению разноязычной по происхождению «демонологической» топонимии, функционирующей на одной и той же территории, простирающейся от Белого моря, Онежского и Белого озер на западе до реки Пинеги на востоке ${ }^{5}$. Материал для исследования извлечен из полевых топонимических картотек Уральского федерального университета (г. Екатеринбург) и Института языка, литературы и истории Карельского научного центра РАН (г. Петрозаводск). Для анализа избраны названия, образованные от топонимических основ, которые наиболее продуктивны и репрезентативны для контактных языков (русского и субстратных) изучаемого региона.

В топонимии русского происхождения наиболее частотны названия, продолжающие праслав. *čbrt-. Чертовы топонимы составляют около 80 \% от

* Уральский федеральный университет (Ural Federal University), пр. Ленина, 51, ком. 306, 620083 Екатеринбург, Россия; berezovich@yandex.ru, toponimist@yandex.ru

** Институт языка, литературы и истории Карельского научного центра РАН (Institute of Language, Literature and History of the Karelian Research Centre of the Russian Academy of Sciences), ул. Пушкинская, 11, 185910 Петрозаводск, Россия; mullonen@sampo.ru

*** Работа выполнена в рамках реализации программы конкурентоспособности УрФУ (2013-2020), научная группа «Народная языковая традиция как источник историко-культурной информации (Русский Север, Средний Урал, Верхнее Поволжье)», проекта РГНФ № 14-04-00243а «Топонимные модели Карелии в пространственно-временном контексте» (2014-2016). Авторы благодарят Т. Н. Бунчук (Сыктывкар), В. В. Напольских (Ижевск), Я. Саарикиви (Хельсинки) за ценные консультации, оказавшие помощь при подготовке статьи.

5 Иначе говоря, рассматривается топонимия Русского Севера в современных границах Архангельской и Вологодской областей и некоторых районов Ярославской и Костромской областей, граничащих с Вологодской областью; анализируются также русские по употреблению топонимы Республики Карелия. 
всех «демонологических» имен в топонимиконе Русского Севера: другие названия, образованные от обозначений нечистой силы (в их основе апеллятивы бес, бука, дьявол, жихарь, кикимора, леший, оборотень, русалка, сатана, скоморох, ynырь, шайтан), значительно уступают чертовыл названиям по своей продуктивности (см.: Березович 2010: 14-57). Более того, эта основа по частотности превосходит любую другую топонимическую основу с сакральной (не только «демонологической») семантикой и существенно опережает следующую за ней основу *svęt-: так, в топонимии Архангельской, Вологодской и северной части Костромской и Ярославской областей насчитывается 275 чертовых топонимов на 220 святых.

Что касается субстратной топонимии, то решено выбрать для анализа материал прибалтийско-финского субстрата, поскольку именно этот слой («верхний» для большей части Русского Севера) наиболее широко представлен и хорошо изучен. Кроме того, для исследования субстратных географических названий необходимо иметь сопоставимые материалы по живой топонимии родственных языков, что в наибольшей степени достижимо именно для прибалтийско-финского субстрата (имеются достаточно полные данные по собственно карельской и вепсской топонимии, а также факты финской). Другие субстратные слои, отмеченные на окраинах Русского Севера, изучены слабее; просмотр словарей и картотек свидетельствует о том, что для некоторых «живых» топонимических систем - например, коми, марийской, - модели номинации с использованием образа черта либо не характерны, либо недостаточно выявлены.

Какая конкретная основа наиболее репрезентативна для прибалтийско-финского материала? Список прибалтийско-финских наименований духов леса, поля, воды, дома и других строений весьма обширен, однако лишь немногие из них закрепились в топонимии. При этом перечень основ несколько разнится в западных и восточных прибалтийско-финских традициях: в западном списке в большей степени ощутимо скандинавское этнокультурное влияние. Среди названий мифологических персонажей, «отметившихся» в восточнофинской топонимии, обычно называют hiisi, kekri, kyöpeli, piru, lempo (Nissilä 1962: 101; 1975: 91), одновременно обращая внимание на их малую продуктивность. Схожая ситуация и в Карелии: в картотеке, включающей более 100 тысяч топонимов этой территории, обнаружилось только несколько названий с основой piru 'черт' и piessa ‘бес' (все в Беломорской Карелии): Pirunsuari ‘Чертов остров’ в оз. Куйтто со скалистыми берегами; Pirukallio 'Чертова скала' на оз. Латваярви, в которой глубокое, как колодец, ущелье; Piessankorpi 'Бесов лес' [Костомукш., Аконлакши], Piessanvuara 'Бесова гора' [Калев., Ювалакша] со скалистыми разломами. Единичными примерами представлена такая лексема, как карел. lempo $(i)$, вепс. lemboi 'черт', причем не на собственно прибалтийско-финской территории, а в виде субстрата в обрусевшем Обонежье: оз. Малое/Большое Лембозеро [Пудож., Авдеевская], залив Лемба [Конд., Викша-река].

На этом скудном фоне прибалтийско-финских топооснов, связанных с называнием нечистой силы, выделяется своей активностью основа hiisi-/hiite-, восхо- 
дящая к соответствующей лексеме hiisi, his, hid, hitto < *hiite, бытующей в ряде прибалтийско-финских языков - финском, эстонском, карельском, водском. Она хорошо известна и в топонимии на территории бытования указанных языков. В Финляндии известно более пятисот названий с основой hiisi-/hiite- (Koski 1967: 119-159), в Карелии их зафиксировано около полусотни. Сама лексема является в прибалтийско-финском языковом пространстве явно западным словом. Считается, что в водский она проникла относительно поздно из финского (SSA 1: 162). Единичные топонимные примеры в ареале вепсского расселения не позволяют убедительно реконструировать ее и в вепсских говорах.

Итак, наша задача - произвести сопоставительное исследование «демонологических» основ hiisi- и черт- в топонимии, обращая внимание на закономерности объектной соотнесенности соответствующих географических названий, их мотивации (и, по возможности, ее динамических изменений), лингвогеографической привязки.

\section{1 РУССКИЕ ПО ПРОИСХОЖДЕНИЮ ТОПОНИМЫ (ОСНОВА ЧЕРТ-)}

Русский материал, учитываемый далее, включает данные по Архангельской, Вологодской областям и смежным с ними территориям Костромской и Ярославской областей. Он был большей частью подробно описан в (Березович 2010: 47-56). Настоящая статья основана на более представительном корпусе топонимов, дополняющем факты, которые изучались в названной работе (привлечены полевые материалы, собранные в 1999-2015 гг.), а при анализе материала избираются несколько иные аспекты.

Объектная соотнесенность. Среди чертовых топонимов (напомним, речь идет о 275 единицах) преобладают названия гидрообъектов (53 \% от общего количества наименований): это болота, омуты, водовороты, рвы и ямы с водой; реки, текущие по глухим лесам или вытекающие из болот и имеющие темную воду; опасные пороги и перекаты; озера, считающиеся «бездонными», и т. п. $75 \%$ топонимов приходится на обозначения ям (омутов, водоворотов), болот и глубоких озер.

На следующем месте по частотности - обозначения объектов хозяйственной деятельности ( $25 \%$ от общего количества чертовых названий). Это наименования покосов, полей (на их долю выпадает 90 \% топонимов этой группы), мостов, дорог, колодцев. Обычно это объекты, неудобные для обработки и опасные: лесные покосы (нередко кочковатые и сырые); неурожайные (каменистые, глинистые и т. п.) поля; отдаленные сельскохозяйственные угодья; места, изобилующие змеями; мосты с подгнивающими опорами; колодцы с загрязненной водой и т. п.

Далее следуют названия населенных пунктов (10\% от общего количества чертовых топонимов) - неофициальные ойконимы, обозначающие деревню или хутор, которые находятся в лесном или болотистом захолустье, далеко от путей сообщения, окружены неплодородными полями и пр. По сути, эту группу можно объединить с предыдущей - как названия «рукотворных» объектов, которые оце- 
ниваются с точки зрения пригодности/непригодности для обработки человеком или проживания.

Отдельную группу составляют названия географических реалий, характеризующих ярко выраженные неровности рельефа (7 \% от общего количества черmoвblx наименований). Из 20 названий 15 приходятся на обозначения оврагов, а 5 - на обозначения гор.

Наконец, имеются наименования лесов и урочищ, представляющих собой, как правило, заброшенные сельскохозяйственные угодья (5 \%).

На основе этого перечня можно выделить некоторые моти вационные закон омерн ост и. Во-первых, как чертовы воспринимаются формы отрицательного рельефа, обычно заполненные водой. Очевидно, «рельефность» можно связать с исходной семантикой основы. Для праслав. *čbrtъ предполагается связь с *čersti, čbrto 'рубить, резать, отделять', при этом, по одной из мотивационных версий, * črtъ понималось как «тот, кто роет» и обозначало подземного духа (ЭССЯ 4: 165-166). Данные топонимии высказываются в пользу этой версии; это подтверждается и на уровне словообразования (ср. многочисленные черторои), и на уровне лексической системности (ср. параллелизм топонимов типа Чертови́к и Ров, приложимых к одному объекту), и на уровне мотивационных контекстов (аргументация приведена в: Березович 2010: 50-51). Нарытое чертом заполняется водой по разным причинам - как вследствие физико-географических условий местности (Русский Север изобилует болотами, глубокими озерами, ямами и пр.), так и вследствие того, что во многих районах России (и шире - в славянском мире) представления о чертях соотносятся прежде всего с водяными духами (Власова 2008: 536; Березович, Виноградова 2012: 522).

Во-вторых, чертовы места имеют отчетливо выраженную хозяйственную оценку: они либо непригодны для «окультуривания» (в первую очередь, кошения и пахоты), либо оно сопряжено с большими трудностями. Эта мотивационная линия, ярко проявляющая земледельческое мировосприятие, очевидно, возникла позднее, чем первая, но тесно с ней связана.

В-третьих, есть смысл говорить о собственно лингвистических обстоятельствах, определяющих мотивационное своеобразие чертовых топонимов. Среди них, на наш взгляд, просматривается внутригнездовая аттракция, которой подвергаются продолжения праслав. * čbrt-, различные по исходной мотивации. Как известно, многие элементы гнезда *čbrt- являются терминами подсечно-огневого земледелия (Куркина 2011: 57-62; ЭССЯ 4: 75-76, 161). К примеру, широко распространено в славянских языках слово *čbrtežb 'подрезание коры' $\rightarrow$ ‘участок леса, на котором произведено подрезание коры' $\rightarrow$ 'расчищенная изпод леса пашня’ (Куркина 2011: 59). Формы, наследующие *čbrtežb, встречаются в диалектной лексике и топонимии практически по всей изучаемой территории. Думается, что и некоторые другие топонимы, восходящие не собственно к *̌̌brtežb (названия типа Черти́ха, Черти́mе, Черти́шное, Чёртишное, отмеченные неоднократно и обозначающие как поля, покосы, так и болота, озера, населенные пункты), изначально могли быть связаны именно с терминологией 
подсечного земледелия. Однако в народном сознании такие названия неизбежно притягиваются к демониму черт, ср. примеры: д. Черти́ха: «Там такая лощина, и вытекает родник, и там находят чёртовы пальцы» [Вил., Якушино]; пок. Чертúxa: «Девчонка однажды потерялась. Нашли её на Чертихе. Она объяснила, что её унесла женщина в красном сарафане» [У-Куб., Никола-Корень]; ур. Черти́ше: «Худое место, чёртовое» [Мез., Дорогорское]. Притяжения наблюдаются даже для топонимических чертежей, имеющих, казалось бы, бо́льшую «словообразовательную защиту» от них: бол. Чертёж: «Видко, черти велися там, место сыроё» [Нейск., Брениха]. Органичность подобных притяжений обусловлена не только фонетически, но и семантически: лесные расчистки могли восприниматься как воистину чертовы места, поскольку их разработка стоила «адского» труда; они отвоевывались у болот и лесов - и были окружены таким ландшафтом, особо «богатым» нечистой силой; почвы быстро истощались - и урочище становилось заброшенным, что тоже вписывается в народную концепцию демонического локуса (см.: Березович 2010: 54). Итак, можно предполагать внутригнездовую аттракцию-«перекодировку» в направлении земледельческий термин $\rightarrow$ демоним. Аналогом является гнездо *lęd-, в котором представлен термин подсечно-огневого земледелия *lędo: 'terra inculta, участок, предназначенный под пашню' $\rightarrow$ 'пустошь, заброшенное поле' $\rightarrow$ 'место обитания нечистой силы’ $\rightarrow$ 'нечистая сила' (ЭССЯ 15: 46). Вероятно, «земледельческое» и «демоническое» значения могли быть связаны друг с другом не «цепочечной» логикой и не отношениями «перекодировки», а существовать как изначально неразрывный и синкретичный смысловой комплекс.

Наконец, упомянем и об еще одном собственно языковом моменте, определяющем мотивацию чертовых названий. Ощутима аттракция чертов $\leftrightarrow$ черный, которая проявляется в том, что чертовы топонимы могут закрепляться как обозначения темных лесных уголков, бездонных озер, рек с грязной водой и т. п. (Березович 2010: 49).

Перейдем к изучению ареальной дистрибуции чертовых топонимов, которое осуществляется (по техническим причинам) для исследуемого топонимического массива за вычетом данных по Карелии. Топонимы с основой черт- фиксируются по всей территории, но есть зоны, где наблюдаются относительные пики и спады. Среди «пиковых» районов - часть вологодского Белозерья (9 чертоbыx названий в Белозерском районе, 10 - в Кадуйском), центральные районы Вологодчины (9 - Сокольский район, 8 - Харовский, 7 - Грязовецкий), зона, прилегающая к Великому Устюгу (7 - Великоустюгский район, 7 - КичменгскоГородецкий, 7 - Никольский), восточные и северные районы Архангельской области (13 - Верхнетоемский район, 9 - Ленский, 8 - Пинежский). Относительные спады отмечены в топонимии следующих зон: Вытегорский район Вологодской области (0 чертовых топонимов, что выглядит странным на фоне «богатых» соседних районов - Белозерского и Кадуйского), восток Костромской области (0 - Октябрьский, Пыщугский районы, 1 - Павинский, Шарьинский), «крайние» восток и север Архангельской области (0 - Мезенский район, 2 - Лешуконский). 
Вопрос о причинах указанных различий очень сложен. На активность чертовой топономинации влияет группа факторов; указать со всей определенностью ведущий фактор для каждой зоны практически невозможно. Перечислим их в качестве сугубо гипотетических и дающих гибкие сочетания друг с другом.

1. На поверхности лежит «ландшафтный» фактор. Легко предположить, что количество чертовых названий должно возрастать в топонимии тех зон, которые особенно богаты болотами, порожистыми реками, глухими лесами и т. п. Возможно, названный фактор наиболее явно «работает» для чертовой топонимии таких районов, как Ленский, Верхнетоемский, Пинежский.

2. Определенное влияние на систему топонимической номинации может оказывать такой фактор, как тип хозяйственной деятельности. В Мезенском и Лешуконском районах, являющихся скорее «охотничьими», чем «земледельческими», чертовых названий практически нет. «Охотничье» мировосприятие имеет иные прагматические доминанты, нежели земледельческое. Охотник воспринимает ландшафт вне оппозиции пригодности/непригодности для обработки - сенокошения, пахоты и т. п. Для него «проходим», по сути, любой участок территории. Это обстоятельство может снижать количество чертовых топонимов.

3. Следующая причина - распространенность на той или иной территории объектов культа, в первую очередь, христианского. Появление таких объектов (особенно крупных - церквей, монастырей) влечет за собой активизацию восприятия ландшафта как арены, где царит крестная сила, которая может взаимодействовать с нечистой. Важно также учесть время христианизации той или иной территории. Скажем, Вологодская область была христианизирована в целом раньше, чем Архангельская (Власова 1995), в ней больше церквей и монастырей, что имеет топонимическое следствие: на Вологодчине больше святых топонимов (4 на район Вологодской области против 3 на район в Архангельской). Особенно это касается центральной зоны Вологодчины: именно здесь было в наибольшей степени развито монастырское землевладение и проживало значительное количество монастырских крестьян.

Осмысление ландшафтной «святости» на уровне топонимии может приводить к появлению явных корреляций святых и чертовых названий. Ср. мотивационный контекст к паре топонимов Святи́к - Чертови́к (озеро и вытекающая из него протока): «Озеро, говорят, Стефан Великопермский крестил, черти-то пошли со Святика да и нарыли всё, вот и назвали Чертовик» [Лен., Сойга] (о подобных корреляциях см. в: Березович 2010: 42-43, 55-56, 78). Но помимо эксплицитно выраженных оппозиций есть, вероятно, и имплицитные. В топонимии ряда территорий чертовы и святые названия неявным образом коррелируют, что выражается в наличии примерно равного количества тех и других названий: например, 7 чертовых - 7 святых [Холм.], 9 чертовых - 8 святых [Белоз.], 1 чертово 1 святое [Сямж.], 0 чертовых - 1 святое [Мез.] и др. Таким образом, частотность чертовых топонимов в ряде случаев может зависеть от того, насколько актуален сценарий святости локуса (и борьбы крестной силы с нечистой) для той или иной территории. Возможно, сказанное следует принимать во внимание для 
объяснения частотности чертовых топонимов в центральных и некоторых западных районах Вологодской области, где, как говорилось выше, было особенно много крупных церквей и монастырей.

В то же время в Вытегорском уезде Олонецкой губернии, по свидетельству историков, позиции христианской религии были наиболее слабыми (Власова 1995: 88). В русской топонимии этого района нет святых названий. Возможно, это повлияло и на отсутствие чертовых топонимов на этой территории (свою роль могло сыграть и отсутствие основы hiisi- в вепсском языке, во многом формирующем картину языковых контактов в этом районе).

4. Если предшествующие факторы носили внеязыковой характер, то сейчас речь идет о факторе внутриязыковом. В тех зонах, где можно предполагать значительное иноязычное влияние на сложение русской топонимической системы, следует учитывать номинативные традиции контактного языка. Так, этот фактор значим для лешуконско-мезенской зоны, где сказывается сильнейшее влияние коми.

В языке коми обозначения нечистой силы в целом не обнаруживают особых номинативных ресурсов ни в топонимической, ни в апеллятивной системах (во фразеологических единицах, семантических и семантико-словообразовательных дериватах от демонима и т. п.). Ощутим контраст с русским языком, в котором слово черт (в меньшей степени бес) обладает исключительной активностью во вторичной номинации. Отсюда версия о том, что причина уменьшения количества чертовых названий в топонимии тех зон, которые контактируют с коми территорией, может быть сугубо ономасиологической: номинативные традиции контактного языка, передающиеся русской топонимической системе.

5. Еще один номинативный фактор связан с явлением языкового табу. При всей активности черта во вторичной номинации, это слово в некоторых коммуникативных режимах, несомненно, подвергалось табуированию. Вероятно, механизм табуирования включался чаще всего в тех случаях, когда речь шла о страшных местах (в том числе «убиенных»). Фактор табу можно допустить «в общем виде», без привязки к определенной территории, поскольку невозможно установить, в каких зонах обсуждаемый механизм работал наиболее действенно. Стоит лишь предполагать, что в связи с обсуждаемым явлением тоже может сказаться контактное влияние (уже не на уровне механизма, а на уровне результата): причины низкой номинативной активности «чертей» в топонимии коми, вероятно, в какой-то мере коренятся в том, что у коми языческая традиция характеризуется высокой степенью сохранности - и явление табуирования представлено более масштабно, чем в русской номинативной системе.

6. Последний фактор тоже носит лингвокогнитивный характер. Широко известна архаичная традиция восприятия локусов в связи с «духами мест», при этом могут номинативно не различаться название локуса и имя genii loci. Эта традиция действует в различных языках, в том числе в славянских, ср. приведенное выше ляд $(<* l e ̨ d o / * l e ̨ d ъ)$. Но если в русском языке (и, кажется, в других славянских традициях) таких случаев относительно немного, то в финно-угорских данная модель гораздо более популярна, что может быть вызвано активностью соответству- 
ющих верований. Показательны в связи с этим рассуждения Л. Н. Виноградовой, отмечающей, что состав духов-«хозяев» локуса наиболее детально разработан в поверьях русского населения европейского Севера: «Вопреки распространенному мнению, такая картина не является типичной для всех славянских традиций и не очевидно, что она отражает древнейшую общеславянскую основу. <..> высокая степень популярности локативных духов-“хозяев” у русских, со всей очевидностью, связана с влиянием финно-угорской мифологии, в которой этот класс демонов занимает первостепенное место» (Виноградова 2013: 501). Поскольку многие объекты топономинации воспринимаются как ландшафтные реалии и одновременно места проживания демонов, можно предположить, что при попадании слова с синкретичной «локативно-демонической» семантикой в топонимию «демонический» компонент попросту оказывается растворенным, особо не акцентированным. Возможно, здесь кроется дополнительное объяснение того, почему мезенско-лешуконская топонимия фактически избегает чертовых топонимов: в условиях активных языковых контактов русская топонимия оказывается лишенной возможности калькировать иноязычные «синкретичные» модели, поскольку у нее мало своих средств передачи подобной комплексной семантики.

Перейдем к анализу прибалтийско-финской топонимии.

\section{2 ПРИБАЛТИЙСКО-ФИНСКИЕ ТОПОНИМЫ (ОСНОВА НIISI-)}

Семантическое наполнение изучаемой лексемы варьирует по языкам, что связано с историческими этапами в ее развитии. Анализ широкого прибалтийско-финского материала, прежде всего, финского и эстонского, показывает, что первоначально слово обозначало расположенное на возвышенности языческое кладбище, на котором проводились определенные обряды, связанные с культом предков (Koski 1967; 1970). Своеобразным алтарем, центром такого кладбища был большой приметный камень. Постепенно слово стало обозначать и выросшую на месте кладбища рощу (особенно в эстонской традиции), которая уже не обязательно ассоциировалась с кладбищем, но сохраняла память о культовом месте. С принятием христианства слово начинает приобретать негативные оттенки семантики: место языческого поклонения, расположенное в глуши. По мере укрепления христианства негативное наполнение расширяется: в частности, с этими местами в западнофинской традиции начинают связывать сюжеты о великанах и троллях, а в восточных говорах слово приобретает значение 'черт, леший'. Эти перипетии высвечиваются в фин. hiisi 'священная роща, место жертвоприношений; кладбище; хозяин леса, тролль', эст. his 'роща, кустарник', hiid 'великан', карел. hiisi ‘ад; дьявол' (SSA 1: 162), ‘леший, водяной’ (KKS 1: 264), в которых отражается, с одной стороны, семантика места, а с другой - населяющей его нечистой силы.

Какой или какие из обозначенных этапов в семантическом развитии слова hiisi отражены в топонимии? К сожалению, сведения об объектах, в названии которых представлена основа hiis(i)-/hiije- < hiit(e)-, отрывочны. Тем не менее, анализ имеющихся материалов по территории карельского Приладожья говорит об 
определенных приоритетах в выборе объектов для называния. Приладожье можно считать в какой-то мере эталонной территорией, поскольку здесь, в ареале формирования древнекарельского этноса, есть основания для поиска наиболее ранних мотивов использования топоосновы hiisi- в карельской традиции. В свою очередь, обращение к карельской традиции вызвано тем, что она, видимо, является наиболее вероятным источником модели с названной основой в субстратной топонимии Русского Севера. Оказалось, что основа продуктивна прежде всего в наименованиях гор, как правило, наиболее высоких, в окрестностях поселения, нередко с крутыми склонами и плоской вершиной: Hiijen/mäk (hiijen- <*hiiden : hiisi, mäk 'гора, холм'), Hiijen/vuor (vuоr 'высокая гора'), Hiis/vuori, Hiijen/kallio (kallio 'скала') и др. Некоторые из них традиционно использовались как места, где водили хороводы, жгли костры в ночь на Иванов день, устраивали качели. Иногда к таким местам приурочены легенды о зарытых кладах или о колдунах. К этому разряду топонимов примыкают названия высоких каменистых мысов (Hiisi/niemi, Hiijen/ niemi), имеющих крутые склоны. С ними также связаны традиции молодежных гуляний. Кроме того, они могли наводить страх на путников. Известно, например, что если путь большой церковной лодки, отвозившей жителей на воскресную службу в церковь в Сортавалу, пролегал мимо мыса Hiisiniemi, то женщин высаживали из лодки в заливе Naislahti 'Женский залив’, и они шли к церкви по тропе, которая обходила мыс стороной (Mallat 2007).

Еще один принципиально важный признак мест, в названиях которых использована основа hiisi- - наличие больших камней, их нагромождений, скальных выходов. «Каменистость» присутствует и в многочисленных финских и эстонских сюжетах о великане Хийси, собиравшем камни в большие кучи, разбрасывавшем огромные глыбы по лесу или пытавшемся бросить такую глыбу на церковь. Такие одиночные большие камни называются Hiidenkivi ‘камень Хийси' и являются культовыми. С «каменистостью», что не менее важно, связана, видимо, и одна из наиболее вероятных этимологий самого слова, возводящая его к скандинавскому истоку со значением 'каменоломня, густой лес, пещера' (SSA 1: 162).

Итак, в средневековой карельской традиции в Приладожье топооснова hiisiмаркировала прежде всего выделяющиеся в окрестностях поселения высоты (горки, высокие мысы) с крутыми каменистыми склонами. Она отмечена и в названиях отдельных приметных камней. Присутствие ее в наименованиях территориально смежных объектов - озер, озерных заливов, островов, болот и др. носит, видимо, вторичный характер и обусловлено переносом по смежности. При этом в топонимии более восточных областей Карелии, осваивавшихся уже в новое время, с названиями возвышенностей - гор и высоких озерных мысов (Hiizi/vuara, Hiid/niemi, Hiijen/niemi), а также отдельных камней количественно явно соперничают озерные наименования (Hiižljärvi, Hiizi/lambi), нередки названия островов (Hiizi/suari) и озерных заливов (Hiiden/guba, Hiiži/lakši). Видимо, такая ситуация связана как с постепенной утратой сакральной функции объектами Hiisi, так и с большей устойчивостью и сохранностью гидронимии. В значительной степени такова же топография объектов с вариантами основы Хиж-/ 
Иж-/Хит- и в традиционно русской Карелии - Поморье и Восточном Обонежье, а также на Русском Севере.

Список русских по употреблению названий включает 47 топонимических гнезд (наименований смежных объектов, образованных от основы hiisi-), которые представлены на территории, тянущейся от Белого моря, Онежского и Белого озер на западе до реки Пинеги на востоке (см. карту). В подавляющем большинстве случаев это действительно гнезда названий смежных объектов, в которых в силу их древности, а также в связи с произошедшим на протяжении столетий, с одной стороны, разрушением, а с другой - разрастанием гнезда, сложно подчас выявить ядро, тот исходный топоним, на базе которого происходило формирование цепи названий смежных объектов.

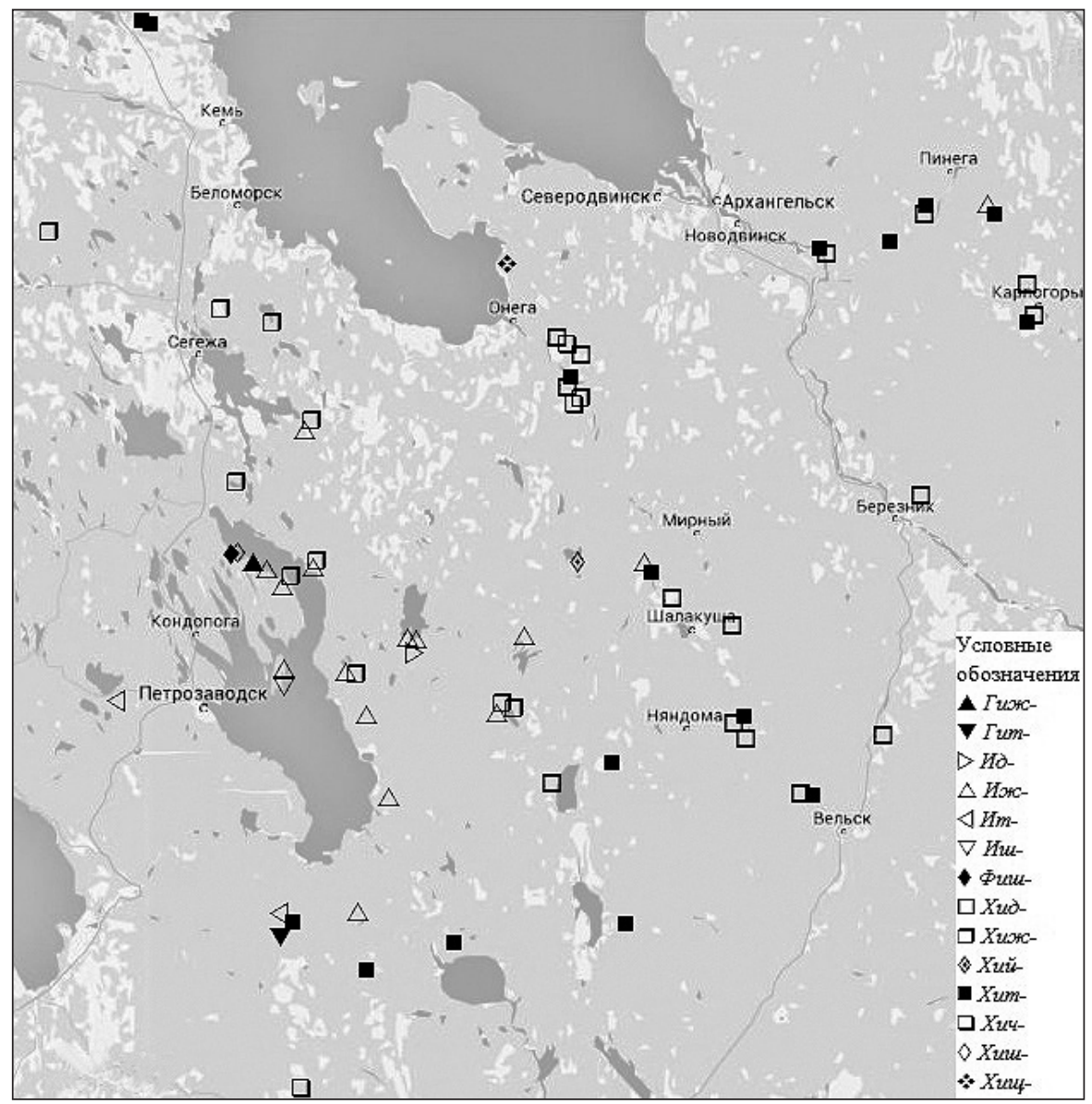

Карта 1: Русские по употреблению названия, образованные от основы hiisi-, в топонимии Русского Севера и Карелии 
При анализе этой субстратной топонимической ситуации логично опираться на те приоритеты называния, которые выявлены на собственно прибалтийско-финском материале, - маркировка топоосновой hiisi- в первую очередь камней, высоких мест, мысов. В нашем списке всего три названия камней, однако, с учетом того, что это микротопонимы, которые, как правило, неустойчивы во времени, они, очевидно, являются рудиментом более обширного и насыщенного ареала, разрушенного временем. К тому же, будучи простыми по структуре (Хuд, $X u m)$, они были явно ядерными, примарными для названий смежных природных и культурных объектов. Отголоски сакральной функции камня Xum $(X u \partial, X u д о)$ отражает контекст: «Камень - страшной, страховище, страх какой» [Онеж., Поле]. 25 \% всех названий списка - наименования гор, в подавляющем большинстве отмеченные на западе ареала - в Беломорье и Обонежье, что хорошо согласуется с их карельскими истоками. Такому генезису модели не противоречит и одна известная восточная фиксация - Хидгора, часть д. Покшеньга - на Пинеге, где выявлен целый ряд убедительных карельских следов в топонимии. Топооснова привязана к доминантным высотам, хорошо выделяющимся на местности, на которых нередко стояли деревни, православные часовни и церкви. Характерный пример - церковь преподобного Александра Свирского на Хижгоре - самой высокой точке южного Кенозерья. С другой стороны, они были известны и как места, связанные с нечистой силой. Такова Ижгора на острове Кижи в Заонежье, о которой в поверье середины XIX в. сказано: «...нечистая сила (лембои) везде водится, но ее любимые жилища на Ишь-горах и Мянь-горах» (Рыбников 1991: 183). В этом же ряду сакральных мест - заонежская Ижгора Хижгора [Медв., Толвуя], известная также под названием Игримыци Креж.

Как и на собственно прибалтийско-финской территории, в субстратной топонимии с основой Хиж- продуктивны названия мысов (10 фиксаций с учетом топонимов с детерминантами -наволок, -нема, -мень, -мина). Ареально они тяготеют к северо-западной части региона - Обонежье и западные районы Архангельской области [Онеж., Плес., Нянд., Холм.], вписываясь в зону субстратной топонимии с карельскими корнями. Все перечисленные в списке мысы находятся в непосредственной близости к поселениям, на некоторых из них были часовни, многие известны как вторичные названия сельскохозяйственных угодий. В одной связке с названиями мысов и гор выступают наименования заливов (6 фиксаций), возникшие, видимо, в ходе переноса топоосновы на смежный объект.

Наиболее многочисленная группа (15 названий) - это наименования сельхозугодий - покосов и полей, при этом сам структурный облик топонимов и наименования смежных объектов в подавляющем большинстве случаев указывают на вторичность этих агронимов, привязанных, как правило, к мысам, камням, иногда озерам, в названиях которых использована топооснова Хиж-/Хид-. Очевидно, и озера (11 фиксаций), а также реки и ручьи (9 названий) являются звеньями в более или менее длинной цепи топонимов и появились в ходе переноса топоосновы с названия ядерного объекта по смежности: оз. Хижсзеро (Хижезеро) в одном гнезде с Хижгорой, Хичезеро - с камнем Хит, оз. Хитминское - с мысом Хитмина, и т. д. 
Названия болот (6 наименований) в смысле их первичности или вторичности классифицировать трудно, поскольку в 4 случаях из 6 они выступают самостоятельно, а не в составе гнезда. В отличие от русской топонимии, где чёртовы болота частотны, в прибалтийско-финской основа hiisi- маркирует иной рельеф местности. Болотистость и малая освоенность, характерная для всей территории Карелии, видимо, не была тем фактором, который вызывал негативную оценку местности. Возможно, сказывался промысловый характер ее освоения и использования. Нельзя исключать того, что на Русском Севере привязка топоосновы Хиж-/Хит- к болотам могла быть спровоцирована влиянием соответствующей русской чертовой модели.

Почему из всех наименований прибалтийско-финских мифологических персонажей, связанных с нечистой силой, практически только слово hiisi оказалось востребованным в топонимии? Возможно, потому, что его семантика изначально включала «местный» компонент: hiisi - это и место (родовое кладбище с каменным алтарем, священная роща, и т. д.), и населяющий его дух.

Какое значение многозначного hiisi отразилось в топонимии Русского Севера? Могло ли слово сохранять раннюю семантику 'языческое кладбище', 'сакральное место' или оно уже было вытеснено значением 'нечистая сила'? По мнению М. Коски, на территории Финляндии, в том числе и в карельском Приладожье, места, в названиях которых присутствует основа hiisi-, перестали быть кладбищами уже в Средневековье, хотя еще длительное время сохраняли функцию культового места (Koski 1967: 221-226). Наши материалы, кажется, подтверждают, что некоторые отголоски семантики культового места еще сохранялись. Недаром в Пудожье и Кенозерье православные церкви и часовни ставились в местах с названием Ижгора, Ижнаволок, Хижгора. Видимо, функцию сакрального места отражают и два зафиксированных в списке названия кладбищ: Хичирга [Онеж., Вонгуда] и Хичим у гор. Бабаево. Если в средневековой западнофинской и эстонской традиции в окрестностях поселения, как правило, существовало два центра - христианская церковь и языческая гора Хийси, которые противопоставлялись друг другу, - то в карельской такого четкого противостояния не было, православная церковь наследовала традицию языческого «святого» места. Очевидно, католичество и лютеранство были более непримиримы к проявлениям язычества. Православие же допускало здесь синкретизм. К тому же, в XVI-XVII столетиях, когда происходило формирование карельской топонимии в Восточном Обонежье и Поморье и ее субстратизация, языческие представления были сильны, и те отрицательные коннотации, которые слово hiisi имеет в современных карельских говорах ('ад; черт; леший; водяной'), на том этапе еще, видимо, не проявились в полную силу, т. е. субстратная топонимия отразила, по крайней мере, в части топонимов, более раннюю семантику лексемы - 'сакральное место'.

С другой стороны, целый ряд контекстов - и в Карелии, и на Русском Севере говорит о том, что в здешних топонимах уже возобладала вторичная пейоративная семантика. Эти места вызывали страх, они были известны как локусы, в кото- 
рых живет нечистая сила. Показательно и то, что несколько топонимов с основами piru и piessa 'черт', которые известны в Карелии, маркируют нагромождение скал, скалистые ущелья, т. е. места, топографически идентичные тем, что маркированы основой hiisi-. Это наводит на мысль о возможных вторичных истоках piru- и piessa- в них - как семантически идентичных заменителей hiisi-, особенно с учетом того, что оба термина (ріги под вопросом) являются относительно поздними заимствованиями в карельском. Отметим, что есть по крайней мере одно документальное свидетельство того, что люд. hiž (hide-) переводилось словом бес: карельская деревня Hidniemi (рус. Гижино) в XVI в. (1563) обозначена как «деревня над Бесовою головою на Бесовом ручью» (ПКОП 1930: 86). Показательна и топография ряда чертовых мест в Прионежье - регионе относительно недавнего карело-вепсского расселения: Чертов Стул - скалистый, отвесный берег Петрозаводской губы Онежского озера, в Заонежье скала Чертовы Bорота (Железные Ворота) [Шунг., Есина], Чертова Тропа, проходящая по дну скалистого ущелья [Шунг., Ажебнаволок]. При этом в топонимии Русского Севера чертовы топонимы практически не маркируют каменистые, скалистые возвышенности. Отсюда можно ставить вопрос о калькированном характере топоосновы черт- в перечисленных топонимах, в оригиналах которых, возможно, использовалась основа hiisi- с семантикой 'нечистая сила'. В свое время на некую корреляцию топонимов с основами Хид- и Черт- обратил внимание А. К. Матвеев: около Хидгорь на берегу Мехреньги находится о-в Чертов, а каргопольская «высокая, заросшая густым еловым лесом и довольно мрачная Хижгора удивительно напоминает многочисленные Бесовы и Чертовы горы, которые автору приходилось наблюдать в различных районах нашей страны» (Матвеев 1976: 183-184).

Топооснова засвидетельствована на Русском Севере в целом ряде фонетических модификаций, для некоторых из них просматриваются ареальные предпочтения: Хиж- на северо-западе ареала, Онежско-Беломорском водоразделе; варианты с утраченным инициальным согласным (Иж-/Ид- и др.) - в Восточном

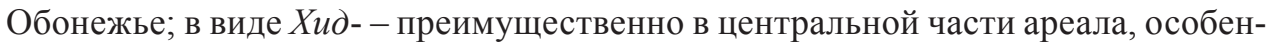
но на р. Онеге; глухой вариант Xum- бытует на южной окраине ареала. При этом возможно сосуществование разных вариантов звучания в одном гнезде (Хид и Хижестров), вызванное, очевидно, особенностями самой исходной лексемы hiisi, имеющей в косвенных падежах основу hiide- (<*hiide-). А. К. Матвеев считал возможным связывать основу Хид- с древними прибалтийско-финскими диалектами Русского Севера. Глухой вариант Xum- мог, по его мнению, возникнуть на русской почве или восходить к прибалтийско-финским производным от hisi типа hitto (Матвеев 2004: 76-78). Этимология лексемы до конца не установлена, для нее предлагались (под вопросом) как исконные (SKES: 74), так и скандинавские (SSA 1: 162) истоки. В целом ареал топоосновы на Русском Севере в значительной степени накладывается на территорию карельской экспансии XV-XVII вв. на восток. Это актуально и для вепсского этноязыкового ареала в Южном Обонежье, где зафиксировано достоверное карельское языковое и культурное наследие. 
В этом контексте показательно практически полное отсутствие «демонологической» топоосновы в вепсской топонимии. Одна из причин в том, что в традиционной культуре вепсов сильны позиции язычества, и представители нехристианского пантеона не несут в полной мере того негативного содержания, которое вызывается христианскими воззрениями. Как следствие - не возникает номинативной базы для идентификации объектов с негативными характеристиками. Очевидно, этим же вызвано отсутствие корреляции «чертовых» и «святых» названий в карельской и вепсской топонимии, которое просматривается в русской системе именований. Кстати, в финской и эстонской топонимии заметна на вепсско-карельском фоне как бо́льшая активность «чертовых» топооснов, так и некоторое сопряжение «чертовых» и «святых» топонимов (Nissilä 1962; Koski 1967; 1970), что может быть вызвано более сильными и продолжительными по времени традициями христианства, причем в его западной, первоначально католической, форме, занимавшей более непримиримую позицию в отношении дохристианских верований, чем православие.

\section{$* * *$}

Сопоставительный анализ двух моделей, соприкоснувшихся в регионе Русского Севера, позволяет наметить некоторые моменты взаимовлияния и взаимопроникновения двух топонимических систем - русской и прибалтийско-финской.

- «Чертовы» топонимы представлены в обеих топосистемах, но в русской их частотность много выше, чем в карельской. При этом изучаемые основы черти hiisi- демонстрируют как исходную семантику основы (не «чертову»), так и собственно «демонологическую». Первоначальные значения в обоих случаях связаны с ландшафтом; вероятно, это обстоятельство обеспечивает приоритет основ черт- и hiisi- в ряду других «демонологических» основ, играющих незначительную роль в топонимической номинации. Можно думать, что в ряде случаев топонимы, образованные от указанных основ, имеют синкретичную семантику, фиксирующую неразрывность (преемственность) представлений о локусе и населяющих его демонах.

- Обе основы используются для называния мест, мало- или непригодных для хозяйственного использования. Оценка таких мест, очевидно, осуществляется с разных позиций. В русской традиции на первый план выдвигаются приоритеты аграрной культуры. В прибалтийско-финской они не столь очевидны. С учетом того, что основа привязана, в первую очередь, к труднопроходимым скалистым горам и в то же время непродуктивна, к примеру, в названиях болот, можно полагать, что за ней стоит взгляд на местность охотника-промысловика.

- Одним из факторов относительно малой продуктивности чертовых топонимов на западной, северо-восточной и южной окраине Русского Севера может быть воздействие финно-угорского субстрата, позиции которого сильны как раз на этих рубежных территориях. В свою очередь, в финно-угорской традиции слабое представительство этой модели может быть обусловлено относительно высокой степенью сохранности языческих традиций и более слабым влиянием христианства. 
- Высвечиваются некоторые моменты взаимовлияния/взаимопроникновения моделей: на западной окраине Русского Севера основа черт- используется для называния гористых и скалистых мест, что несвойственно русской топонимии данной территории, но нормативно для прибалтийско-финской. В то же время на Русском Севере прибалтийско-финская основа Хиж- востребована в наименованиях болот, что может быть спровоцировано соответствующей русской моделью номинации.

\section{Сокращения в названиях районов}

Белоз. - Белозерский район Вологодской области Вил. - Вилегодский район Архангельской области Калев. - Калевальский национальный район Республики Карелия Конд. - Кондопожский район Республики Карелия Костомукш. - Костомукшский городской округ Республики Карелия Лен. - Ленский район Архангельской области Медв. - Медвежьегорский район Республики Карелия Мез. - Мезенский район Архангельской области Нейск. - Нейский район Костромской области Нянд. - Няндомский район Архангельской области Олонец. - Олонецкий национальный район Республики Карелия Онеж. - Онежский район Архангельской области Плес. - Плесецкий район Архангельской области Пудож. - Пудожский район Республики Карелия Сямж. - Сямженский район Вологодской области У-Куб. - Усть-Кубенский район Вологодской области Холм. - Холмогорский район Архангельской области

\section{Литература}

БЕРЕЗОВИЧ, Е. Л. (2010) Русская топонимия в этнолингвистическом аспекте: Мифопоэтический образ пространства. 2-е изд., испр. и доп. Москва: КомКнига.

БЕРЕЗОВИЧ, Е. Л./Л. Н. ВИНОГРАДОВА (2012) «Черт.» Н. И. Толстой (Ред.) Славянские древности: этнолингвистический словарь в 5 томах, 5: С (Сказка) - Я (Ящерица). Москва: Международные отношения, 519-527.

ВИНОГРАДОВА, Л. Н. (2013) «Перспективы изучения персонажей народной демонологии в общеславянском масштабе: Категория духов типа genii loci.» А. М. Молдован (Отв. ред.), Письменность, литература, фольклор славянских народов. История славистики. ХV Международный съезд славистов. Доклады российской делегащии. Москва: Древлехранилище, 486-504.

ВЛАСОВА, И. В. (1995) «Население центральных районов Русского Севера (XIIXX вв.).» Этнографическое обозрение 2, 76-90. 
ВЛАСОВА, М. (2008) Энщиклопедия русских суеверий. Санкт-Петербург: Азбука-классика.

КУРКИНА, Л. В. (2011) Культура подсечно-огневого земледелия в зеркале языка. Москва: Азбуковник.

MATBEEB, А. К. (1976) «Топонимические этимологии. VIII.» Советское финноугроведение 3, 182-186.

MATBEEB, А. К. (2004) Субстратная топонимия Русского Севера, II. Екатеринбург: Издательство Уральского университета.

Рыбников - РАЗУМОВА, А. П./И. А. РАЗУМОВА/Т. С. КУРЕЦ (Сост.) (1991) Песни, собранные П. Н. Рыбниковым, 3. Петрозаводск: Карелия.

ЭССЯ - ТРУБАЧЕВ, О. Н. (Отв. ред.) (1974-) Этимологический словарь славянских языков: Праславянский лексический фонд. Вып. 1-. Москва: Наука.

KKS - VIRTARANTA, Pertti/Raija KOPONEN/Marja TORIKKA/Leena JOKI (ред.) (1968-2005) Karjalan kielen sanakirja, 1-6. Helsinki: Suomalais-Ugrilainen Seura. KOSKI, Mauno (1967) Itämerensuomalaisten kielten hiisi-sanue: Semanttinen tutkimus: 1. Turku: Turun yliopisto.

KOSKI, Mauno (1970) Itämerensuomlaisten kielten hiisi-sanue: Semanttinen tutkimus: 2. Turku: Turun yliopisto.

MALLAT, Kaija (2007) Naiset rajalla. Kyöpeli, Nainen, Naara(s), Neitsyt, Morsian, Akka ja Ämmä Suomen paikannimissä. Helsinki: Suomalaisen Kirjallisuuden Seura.

NISSILÄ, Viljo (1962) Suomalaista nimistöntutkimusta. Helsinki: Suomalaisen Kirjallisuuden Seura.

NISSILÄ, Viljo (1975) Suomen Karjalan nimistö. Joensuu: Karjalaisen kulttuurin edistämissäätiö.

SKES - TOIVONEN, Yrjö Henrik/Erkki ITKONEN/Aulis J. JOKI/Reino PELTOLA (ред.) (1955-1981) Suomen kielen etymologinen sanakirja, 1-7. Helsinki: Suomalaisen Kirjallisuuden Seura.

SSA - ITKONEN, Erkki/Ulla-Maija KULONEN (ред.) (1992-2000) Suomen sanojen alkuperä: etymologinen sanakirja, 1-3. Helsinki: Suomalais-Ugrilainen Seura.

\section{Аннотация \\ «ДЕМОНОЛОГИЧЕСКИЕ» НАЗВАНИЯ В РУССКОЙ И СУБСТРАТНОЙ ТОПОНИМИИ РУССКОГО СЕВЕРА И КАРЕЛИИ (НА МАТЕРИАЛЕ ОСНОВ ЧЕРТ- И НIISI-)}

В статье производится сопоставительное исследование «демонологических» основ hiisi- и черт- в русской по употреблению топонимии Русского Севера (Архангельская, Вологодская области, прилегающие районы Ярославской и Костромской областей), а также Республики Карелия.

В топонимии русского происхождения наиболее частотны (80 \% всех «демонологических» имен) названия с основой чёрm-< праслав. *č́rt-. Места, названные «чер- 
товыми» топонимами, обладают рядом общих признаков: часто это топообъекты отрицательного рельефа, обычно заполненные водой; хозяйственное освоение таких мест либо невозможно, либо значительно затруднено. Популярность основы чёрт- в топонимии поддерживается аттракцией к продолжениям * čbrtežb 'расчищенная изпод леса пашня', а также может быть связана с архаичной традицией восприятия локусов в соотношении с «духом места». Факторами, способствующими увеличению количества чёртовых названий, являются особенности ландшафта (количество таких топонимов возрастает в зонах, богатых болотами, быстрыми реками, глухими лесами и т. п.); земледельческий тип хозяйственной деятельности; значительное количество церквей и монастырей. Факторы, снижающие продуктивность чёртовой номинации в топонимии, таковы: охотничий тип хозяйственной деятельности; номинативные традиции контактных языков (например, низкая продуктивность соответствующего слова в коми языке); языковое табу.

В прибалтийско-финской топонимии выделяется основа hiisi-/hiite- < *hiite. Hiisi первоначально обозначало расположенное на возвышенности языческое кладбище, центром которого был большой приметный камень. Постепенно слово стало обозначать и рощу, выросшую на месте кладбища. По мере распространения христианства, в восточных говорах слово приобрело значение 'черт, леший'. В субстратной топонимии Русского Севера наиболее вероятным источником данной модели является карельская традиция. В топонимии карельского Приладожья основа продуктивна прежде всего в наименованиях наиболее высоких гор в окрестностях поселения. Примерно четверть всех субстратных названий, имеющих основу hiisi-, также составляют наименования гор (большинство из них расположено на западе ареала - в Беломорье и Обонежье). Топооснова привязана к хорошо заметным на местности возвышенностям, где нередко стояли деревни, а также православные часовни и церкви. С другой стороны, они были известны и как места, связанные с нечистой силой. На Русском Севере топооснова засвидетельствована в нескольких фонетических модификациях: Хиж- на северо-западе ареала, на Онежско-Беломорском водоразделе; варианты с утраченным инициальным согласным (Иж-/Ид- и др.) - в Восточном Обонежье; Хид- - преимущественно в центральной части ареала, особенно на p. Онеге; Хит- - на южной окраине ареала. Сосуществование разных вариантов на одной и той же территории (Хид и Хижестров), возможно, объясняется тем, что исходная лексема hiisi в косвенных падежах имеет основу hiide- (< *hiide-). Ареал топоосновы на Русском Севере (от Белого моря, Онежского и Белого озер на западе до р. Пинеги на востоке) в значительной степени накладывается на территорию карельской экспансии XV-XVII вв. на восток.

Ключевые слова: топонимия, субстрат, русский язык, прибалтийско-финские языки, языковые контакты 


\section{Abstract \\ “DEMONOLOGICAL” ROOT ČERT- AND HIISI- IN RUSSIAN TOPONYMY OF THE RUSSIAN NORTH AND THE REPUBLIC OF KARELIA}

The paper presents a comparative study of "demonological" root čert- and hiisi- in the currently used Russian toponymy of the Russian North (Arkhangelsk, Vologda regions, the surrounding areas of Yaroslavl, Kostroma regions), and the Republic of Karelia.

In the toponymy of Russian origin, the most frequent names are toponyms with the root čert- (80\% of "demonological" names), which continue Proto-Slavic *čbrt-. The places named using čert- have a number of common features: often these are places with a negative relief, usually filled with water (names of water objects dominate in this type); the economic exploitation of čert-places is either impossible or extremely difficult. The popularity of the root čert- in toponymy is also supported by the use of * čbrtež 'cleared arable land', and may be associated with the archaic tradition of the perception of a place in relation to the "spirit of the place". There are certain factors which caused an increase of čert- toponyms: "landscape" (their number increases in the areas rich with swamps, rapid rivers, dense forests etc.); agricultural activity; a significant number of churches and monasteries. Factors mitigating the productivity of čert- toponyms are: hunting activity; the onomastic tradition of contact languages (e.g., low productivity of the corresponding word in Komi); linguistic taboos.

In Finnic toponymy the corresponding root is hiisi-/hiite-, which can be traced back to *hiite. The popularity of the root in toponymy is connected with the semantics that originally included a "local" component. Hiis $i$ was originally used for a pagan cemetery located on a hill, with a large conspicuous stone in the centre. Gradually the word came to mean a grove which developed on the site of the cemetery. With the spread of Christianity in the eastern dialects, the word acquired the meaning 'devil'. The most likely source of the model in the substrate toponymy of the Russian North is the Karelian tradition. In the toponymy of Karelian Priladozhye, this root is used to denote primarily the highest mountains located near a settlement. About a quarter of the names with the root hiisi- in the substrate toponymy also denote mountains, most of them located in the west of the area, that is on the White Sea and in Obonezhye. This toponymic root referred to prominent heights in the territory where villages often stood, as well as Orthodox chapels and churches. On the other hand, they are known as places connected with impure force. This toponymic root is evident in the Russian North with different phonology: Hiž- in the north-west, on the Onega-White Sea watershed; forms with the loss of the initial consonant (Iž-, Id- et al.) in Eastern Obonezhye; Hid- mainly in the central area, especially on Onega; Hit- in the south. The coexistence of different variants in the same area (Hid and Hižestrov) reflected the fact that hiisi took the form hiide- $\left(<^{*}\right.$ hii $\left.\delta e-\right)$ in obliqiue cases. The whole area where the toponymic root occurs in the Russian North (from the White Sea, the Lake Onega and the White Lake in the west to Pinega in the east) largely corresponds to the territory of the eastward Karelian expansion in the fifteenth to seventeenth centuries.

Keywords: toponymy, substrate, Russian language, Finnic languages, language contact 


\section{Povzetek \\ »DEMONOLOŠKA« POIMENOVANJA V RUSKI IN SUBSTRATNI TOPONIMIJI RUSKEGA SEVERA IN KARELIJE (NA GRADIVU OSNOV ČERT- IN HIISI-)}

V članku je podana primerjalna raziskava »demonoloških « osnov hiisi- in čert- v toponimiji Ruskega Severa (Arhangelska in Vologodska oblast z bližnjimi predeli Jaroslavske in Kostromske oblasti) in Republike Karelije, kot se uporablja v ruskem jeziku.

$\mathrm{V}$ toponimiji ruskega izvora so najbolj pogostna poimenovanja z osnovo čërt- $<$ psl. * čbrt- (80\% vseh »demonoloških« imen). Kraji, ki jih označujejo »hudičevi« toponimi, imajo več skupnih značilnosti: pogosto so to topografski objekti negativnega reliefa, navadno zapolnjeni z vodo; gospodarska osvojitev takšnih krajev je bodisi nemogoča, bodisi dodobra otežena. Popularnost osnove čërt- v toponimiji povečuje naslonitev na kontinuante leksema * čbrtežb »orna zemlja, pridobljena z iztrebitvijo gozda«, lahko pa je povezana tudi z arhaično tradicijo dojemanja krajev glede na »duh kraja«. Dejavniki, ki vplivajo na povečanje števila hudičevih poimenovanj, so posebnosti pokrajine (število takšnih toponimov naraste na območjih, kjer je veliko močvirij, hitrih rek, neprehodnih gozdov ipd.); poljedelski tip gospodarske dejavnosti, precejšnje število cerkva in samostanov. Dejavniki, ki znižujejo produktivnost hudičeve nominacije v toponimiji, pa so: lovski tip gospodarske dejavnosti, nominativne tradicije jezikov v stiku (na primer, nizka produktivnost ustrezne besede v jeziku Komi), jezikovni tabu.

$\mathrm{V}$ pribaltsko-finski toponimiji izstopa osnova hiisi-/hiite- $<*$ hiite. Hiisi je prvotno označevalo na vzpetini ležeče pogansko pokopališče, katerega središče je bil velik opazen kamen. Postopoma je beseda začela označevati tudi gozdič, ki je zrasel na kraju, kjer je bilo prej pokopališče. S širjenjem krščanstva je beseda v vzhodnih govorih prejela pomen 'hudič, gozdni duh'. V substratni toponimiji Ruskega Severa je najbolj verjeten vir tega modela karelska tradicija. V toponimiji karelskega Priladožja (= območja ob jezeru Ladoga) je osnova poduktivna predvsem v poimenovanjih najvišjih vzpetin v okolici naselbine. Približno četrtina vseh substratnih imen, ki vsebujejo osnovo hiisi-, prav tako predstavljajo poimenovanja vzpetin (večina od njih leži v zahodnem delu areala $-\mathrm{v}$ Belomorju in Obonežju). Topografska osnova se nanaša na dobro vidne vzpetine, kjer so marsikdaj stale vasi ali tudi pravoslavne kapele in cerkve. Po drugi strani so bila znana tudi kot kraji, povezani z zlimi duhovi. Na Ruskem Severu je ta topografska osnova izpričana v več fonetičnih različicah: Hiž- na severovzhodu areala, na Oneško-Belomorski razvodnici; variante z opuščenim vzglasnim soglasnikom (Iž-/Ididr.) - v Vzhodnem Obonežju; Hid- - pretežno v osrednjem delu areala, zlasti ob reki Onegi; Hit- - na južnem robu areala. Soobstoj različnih variant na istem ozemlju (Hid in Hižestrov) je morda razložljiv z dejstvom, da ima izhodiščni leksem hiisi v stranskih sklonih osnovo hiide- (<*hiide-). Areal te topografske osnove na Ruskem Severu (od Belega morja, Oneškega in Belega jezera na zahodu do reke Pinege na vzhodu) se v precejšnji meri pokriva z ozemljem karelske širitve na vzhod v 15.-17. stol.

Ključne besede: toponimija, substrat, ruščina, finski jeziki, jezikovni stik 